\title{
Environmental variations in a semi-enclosed embayment (Amvrakikos Gulf, Greece) - reconstructions based on benthic foraminifera abundance and lipid biomarker pattern
}

\author{
S. Naeher ${ }^{1,2}$, M. Geraga ${ }^{3}$, G. Papatheodorou ${ }^{3}$, G. Ferentinos ${ }^{3}$, H. Kaberi ${ }^{4}$, and C. J. Schubert ${ }^{1}$ \\ ${ }^{1}$ Eawag - Swiss Federal Institute of Aquatic Science and Technology, Department of Surface Waters - Research and \\ Management, Seestrasse 79, 6047 Kastanienbaum, Switzerland \\ ${ }^{2}$ ETH Zurich, Institute for Biogeochemistry and Pollution Dynamics, Universitaetstrasse 16, 8092 Zurich, Switzerland \\ ${ }^{3}$ University of Patras, Department of Geology, Laboratory of Marine Geology and Physical Oceanography, \\ 26504 Patras, Greece \\ ${ }^{4}$ Hellenic Centre for Marine Research, Institute of Oceanography, 46.7 km Athens-Sounio Avenue, 19013 Anavyssos, Greece \\ Correspondence to: S. Naeher (sebastian.naeher@upmc.fr)
}

Received: 1 June 2012 - Published in Biogeosciences Discuss.: 22 June 2012

Revised: 8 November 2012 - Accepted: 17 November 2012 - Published: 11 December 2012

\begin{abstract}
The evolution of environmental changes during the last decades and the impact on the living biomass in the western part of Amvrakikos Gulf was investigated using abundances and species distributions of benthic foraminifera and lipid biomarker concentrations. These proxies indicated that the gulf has markedly changed due to eutrophication. Eutrophication has led to a higher productivity, a higher bacterial biomass, shifts towards opportunistic and tolerant benthic foraminifera species (e.g. Bulimina elongata, Nonionella turgida, Textularia agglutinans, Ammonia tepida) and a lower benthic species density. Close to the Preveza Strait (connection between the gulf and the Ionian Sea), the benthic assemblages were more diversified under more oxygenated conditions. Sea grass meadows largely contributed to the organic matter at this sampling site. The occurrence of isorenieratane, chlorobactane and lycopane supported by oxygen monitoring data indicated that anoxic (and partly euxinic) conditions prevailed seasonally throughout the western part of the gulf with more severe oxygen depletion towards the east. Increased surface water temperatures have led to a higher stratification, which reduced oxygen resupply to bottom waters. Altogether, these developments led to mass mortality events and ecosystem decline in Amvrakikos Gulf.
\end{abstract}

\section{Introduction}

Coastal development, pollution and a range of anthropogenic activities including extensive agriculture, aquaculture, urban and industrial wastes are main causes of decline and loss of coastal habitats observed over the last decades (Airoldi and Beck, 2007; Diaz and Rosenberg, 2008).

Amvrakikos Gulf, located in northwestern Greece, is a semi-enclosed embayment characterized by a complex lagoonal system and an extensive delta (Kapsimalis et al., 2005). It has a fjord-like oceanographic regime because of a shallow sill, which reduces deep-water exchange with the ocean (Ferentinos et al., 2010). The gulf is protected under the international Ramsar Convention as Wetlands of International Importance. In addition it is designated as a Special Protection Area (SPA), according to the European Union Directive 79/409/EU, and it is included in the Natura 2000 Network. Despite the efforts, which have been made for the protection and conservation of this unique area, the western part of the gulf is suffering from seasonal hypoxia (oxygen concentrations $<2 \mathrm{mg} \mathrm{L}^{-1}$ ), whereas the eastern part is also affected by seasonally anoxic conditions (oxygen concentrations $<0.5 \mathrm{mg} \mathrm{L}^{-1}$ ) (Kountoura and Zacharias, 2011). This was caused by the excessive use of fertilizers, the increase in animal stocks, intensive fish farming and domestic effluents for the last 20 to $30 \mathrm{yr}$ (Ferentinos et al., 2010; Kountoura and Zacharias, 2011). Recently, in February 2008 the 
environmental stress in the gulf resulted in a sudden massive mortality of fish in aquaculture rafts in the northeastern part of the gulf (Ferentinos et al., 2010).

The purpose of the present paper is to illustrate the evolution of the environmental conditions in the Amvrakikos Gulf over the last $50 \mathrm{yr}$ by means of sedimentary proxies. Benthic foraminifera have been proven useful in the reconstruction of palaeoenvironmental conditions since changes in abiotic and biotic parameters such as salinity, nutrient content, oxygen concentration, substrate, water depth and pollution do modify benthic assemblages (Scott et al., 1979; Jorissen, 1987; Debenay et al., 2005; Murray, 2006). Due to their short reproductive life cycles, benthic foraminifera can be used as proxies to reconstruct short-term environmental changes in oxygen conditions, organic matter (OM) supply and lithology at the sea bottom (Murray, 2001).

More specific in environments where oxygen depletion in the bottom water occurs, benthic foraminifera populations and their diversity are usually reduced and the assemblages are dominated by relatively tolerant species (Sen Gupta and Machain-Castillo, 1993). The changes in benthic assemblage characteristics have been used to evaluate the past evolution of oxygen depletion in a wide spectrum of coastal environments (Filipsson and Nordberg, 2004; Platon et al., 2005).

Lipid biomarkers have been used as tracers for human alteration and eutrophication of water bodies (e.g. Smittenberg et al., 2004; Naeher et al., 2012). Specific indicators of severe oxygen depletion are the pigments isorenieratene, chlorobactene and okenone (or related derivatives), which have been used to trace photic zone euxinic conditions (e.g. Brocks and Summons, 2003). Apart from oxygen depletion, water column properties such as stability of stratification and salinity can be traced by tetrahymanol and gammacerane (Sinninghe Damsté et al., 1995; Thiel et al., 1997; Bechtel and Schubert, 2009), whereas long-chain alkenones have been proven useful in reconstructing surface water temperatures (Prahl and Wakeham, 1987; Müller et al., 1998).

In this study, the combined approach of benthic foraminifera and sedimentary lipid biomarker proxies in two sediment cores was used to characterise environmental changes and the implications for living biomass during the recent history in Amvrakikos Gulf. Changes in eutrophication within the last decades and the role of the ocean regarding water exchange and oxygen supply to the gulf was studied. The effects of low oxygen concentrations (traced by lipid biomarkers) on foraminifera assemblages (adaptation, community shifts, species extinction) were determined. Furthermore, the applicability and robustness of biotic and geochemical proxies for reconstructions of such environmental alterations was tested.

\section{Regional setting}

Amvrakikos Gulf was formed during the mid-Quaternary period (ca. 50-11 ka BP; Kapsimalis et al., 2005; Anastasakis et al., 2007) and is approximately $35 \mathrm{~km}$ long and 6-15 km wide (Fig. 1). It is separated from the open Ionian Sea by a beach-barrier complex and is connected to the open sea through a narrow, elongated channel, the Preveza Strait, which is approximately $6 \mathrm{~km}$ long, 0.8 to $2.5 \mathrm{~km}$ wide and $20 \mathrm{~m}$ deep. The delta of the Arachthos and Louros Rivers and associated lagoons are located at the northern border of the gulf.

The water column is stratified during most time of the year with a brackish surface layer and a saline bottom layer, which are separated by a sharp halocline between 8 and $12 \mathrm{~m}$ (Ferentinos et al., 2010). The surface layer is well oxygenated with concentrations ranging from 7.5 to $9 \mathrm{mg} \mathrm{L}^{-1}$, but the dissolved oxygen content in the bottom water layer only reaches $0-2 \mathrm{mg} \mathrm{L}^{-1}$ during the summer months in the western part and year-round in the eastern part of the gulf (Ferentinos et al., 2010 and unpublished data). Brackish surface water flows out of the gulf, whereas saline water enters into the bottom water. Summer months temperatures and salinity in the surface water ranged between 28.3 and $29.3^{\circ} \mathrm{C}$ and between 32.9 and 33.7, respectively. Temperatures in the bottom water ranged between 15.8 and $16.0^{\circ} \mathrm{C}$, whereas the salinity was around 37.7. These values were recorded seasonally for two years (2009-2010; Ferentinos et al., 2010). Similar ranges were also reported by Kountoura and Zacharias (2011) and in 1987 by Hellenic Centre for Marine Research (unpublished data). Seasonal hypoxia has been documented at the sampling sites since the last 2-3 decades (Kountoura and Zacharias, 2011).

Since the 1970s the gulf has been altered, mostly due to extensive agriculture, aquaculture and urban development, and the establishment of oil stations along the southern border of the gulf. Furthermore, since the construction of two dams the run-off of the Arachthos River has been controlled. Now also the surface water layer suffers occasionally from oxygen depletion (Ferentinos et al., 2010). In 2008, water with a higher density filled the deeper parts of the basin and lifted the anoxic layer, which led to a massive fish mortality event (Ferentinos et al., 2010). Fish mortality events in aquaculture rafts have also been observed in the past (1988, 1992 and 1998), although less intense than in 2008 (Ferentinos et al., 2010).

\section{Methods}

Two short sediment cores were retrieved in October 2010 from Amvrakikos Gulf by a KC Kajak sediment core sampler. Core Amvr15 (42 cm long) was collected from an area close to the entrance of the gulf $\left(38^{\circ} 56^{\prime} 53^{\prime \prime} \mathrm{N}, 20^{\circ} 48^{\prime} 31^{\prime \prime} \mathrm{E}\right)$ at a water depth of $32 \mathrm{~m}$ (Fig. 1). The $30 \mathrm{~cm}$ long core 


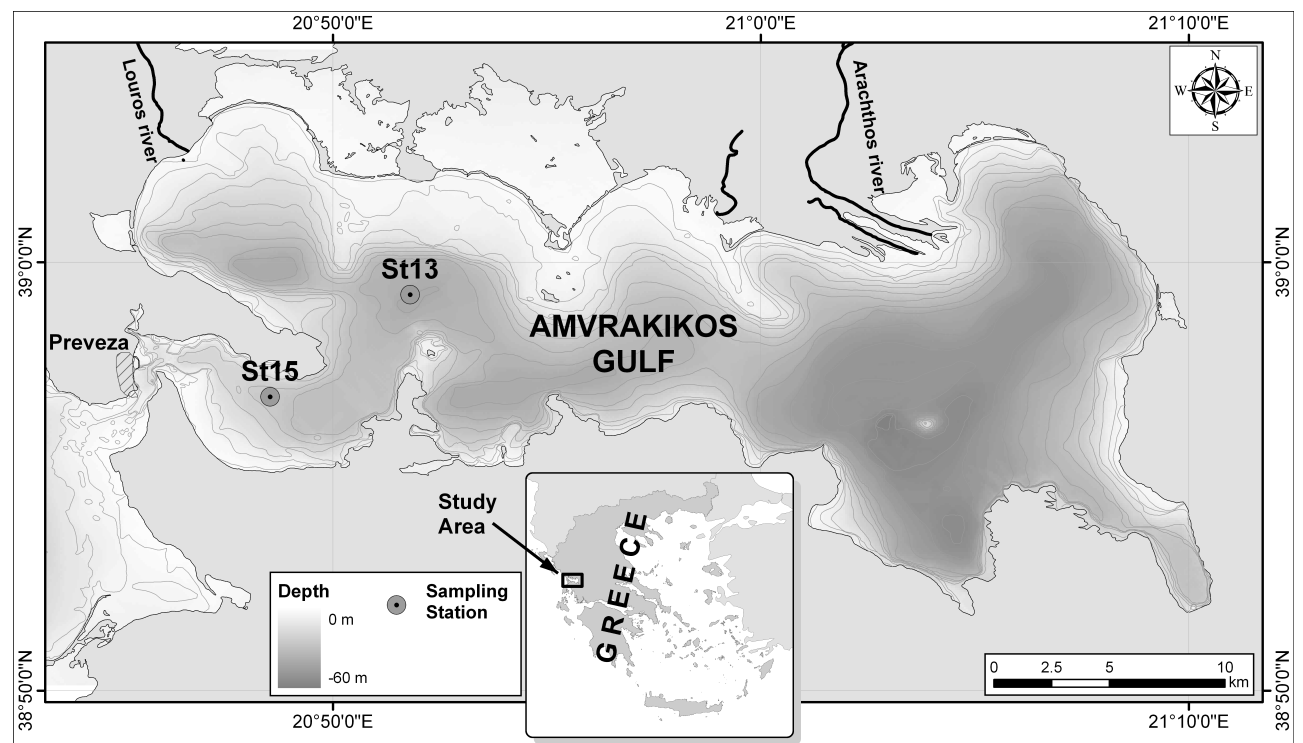

Fig. 1. Map of Amvrakikos Gulf, Greece. The major rivers (Louros and Arachthos Rivers), the Preveza Strait (connection with the Ionian Sea) and the sampling stations of cores Amvr13 and Amvr15 are illustrated.

Amvr13 was retrieved from the inner part of the gulf $\left(38^{\circ} 59^{\prime} 15^{\prime \prime} \mathrm{N}, 20^{\circ} 51^{\prime} 48^{\prime \prime} \mathrm{E}\right)$ at a water depth of $40 \mathrm{~m}$ (Fig. 1).

The actual sediment accumulation rates at the sampling sites were calculated from the vertical distribution of ${ }^{210} \mathrm{~Pb}$ in the cores, following the constant rate of supply (CRS) model of Appleby and Oldfield (1978). The downcore ${ }^{210} \mathrm{~Pb}$ activity was determined through the activity of its $\alpha$-emitting granddaughter ${ }^{210} \mathrm{Po}$, assuming secular equilibrium with ${ }^{210} \mathrm{~Pb}$. The supported ${ }^{210} \mathrm{~Pb}$ activities, which correspond to sediment layers deposited earlier than the last 100-120 yr, were calculated from the vertical profiles of ${ }^{226} \mathrm{Ra}$ published by Tsabaris et al. (2011) in the same area.

Benthic foraminifera were studied on 29 samples from core Amvr15 and 20 samples from core Amvr13. The sampling interval for faunal analyses ranged between 0.5 and $2 \mathrm{~cm}$ in each core. The samples were washed over a $63 \mu \mathrm{m}$ sieve and dried in an oven. At least 200 specimens of benthic foraminifera were picked and identified from each sample; a microsplitter device was used in cases where foraminifera were very abundant. Each taxon was expressed as a percentage of the total benthic assemblage. An estimation of the species diversity was performed using the $H(s)$ index following the Shannon-Wiener equation (Shannon, 1948; Buzas and Gibson, 1969). The ratio of the number of benthic foraminifera per weight of dry sediment $(>63 \mu \mathrm{m})$ was used as an index of benthic foraminifera productivity (Blackwelder et al., 1996). Hierarchical cluster analysis (R-mode) was performed on 18 benthic foraminifera species and genera, which were sufficiently abundant in both cores. The tree diagram was constructed using the Ward's method based on Euclidian distance on SPSS software.
Bulk parameters were analysed and measured as described previously (Naeher et al., 2012): in short, total carbon (TC), total nitrogen (TN) and total organic carbon (TOC) were determined on untreated and decalcified sediment samples, respectively, with errors of up to $\pm 0.2 \mathrm{wt} \%$ by means of an elemental analyser (Carlo Erba 2500). The total inorganic carbon (TIC) was calculated from the difference between TC and TOC. The isotopic composition of OM $\left(\delta^{13} \mathrm{C}_{\mathrm{TOC}}\right.$ and $\delta^{15} \mathrm{~N}$ ) was analysed by an Isoprime mass spectrometer connected to an elemental analyser (Carlo Erba 2500). The error was $\pm 0.3 \%$ and values are reported against the international standards Vienna Pee Dee Belemnite (VPDB, carbon) and air (nitrogen). The chlorin index (CI) and total chlorin concentrations were determined according to Schubert et al. (2005). For biomarker analysis, the same extraction and treatment product was used as described in Naeher et al. (2012). An internal standard was added for quantification ( $\alpha$-cholestane, $\mathrm{C}_{19} n$-fatty acid, $\mathrm{C}_{19} n$-alcohol) before extraction with $\mathrm{MeOH} / \mathrm{DCM}$. After saponification and separation of fatty acids (FA) and neutrals, the latter were further separated into apolar and polar fractions over $\mathrm{NH}_{2}$ columns (Hinrichs et al., 2003). The polar fraction was derivatized with BSTFA for $1 \mathrm{~h}$ at $80^{\circ} \mathrm{C}$. FA were converted into methyl esters with $14 \% \mathrm{BF}_{3} / \mathrm{MeOH}$. FA double bond positions were determined according to Spitzer (1997). A sample aliquot of the polar fraction was desulfurized with Raney nickel catalyst (Sinninghe Damsté et al., 1988), followed by hydrogenation for $2 \mathrm{~h}$ with $\mathrm{PtO}_{2}$ as catalyst in a solution of concentrated acetic acid and ethyl acetate $(1: 1, v: v)$. Instruments and measurement conditions are described in Naeher et al. (2012). Alkenones were quantified on an Agilent 7890A GC system, equipped with an Agilent column 


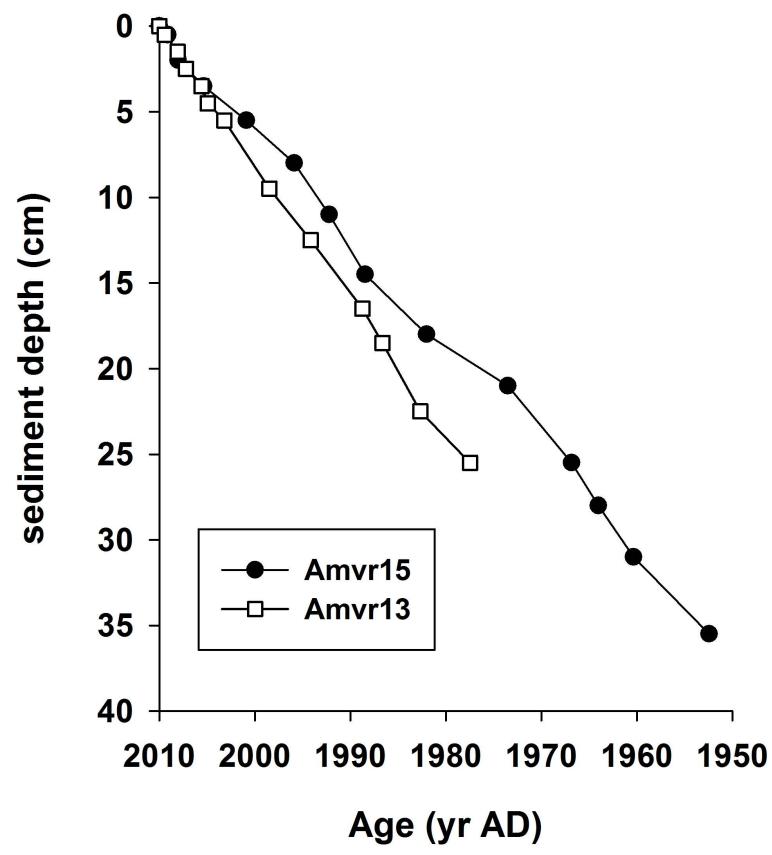

Fig. 2. Age models of cores Amvr15 and Amvr13 based on the specific activity of ${ }^{210} \mathrm{~Pb}$ in the sediment.

(30 m long $\times 320 \mu \mathrm{m}$ inner diameter $\times 0.32 \mu \mathrm{m}$ film thickness) and a flame ionization detector (FID). The GC oven temperature program was $70^{\circ} \mathrm{C}$ to $180^{\circ} \mathrm{C}$ at $40^{\circ} \mathrm{C} \mathrm{min}^{-1}$, then to $320^{\circ} \mathrm{C}$ at $2^{\circ} \mathrm{C} \mathrm{min}^{-1}$ and held for $10 \mathrm{~min}$.

\section{Results}

\subsection{Sediment cores and age model}

The sediment in cores Amvr15 and Amvr13 consisted of grey mud. The colour of the sediments in the top $5 \mathrm{~cm}$ in each core appeared darker in relation to the rest of the core. At the sampling site of core Amvr15, seagrass meadows were present on the sediment surface.

According to the CRS model, the estimated average sediment accumulation rates in core Amvr 15 were $0.6 \mathrm{~cm} \mathrm{yr}^{-1}$ and $0.8 \mathrm{~cm} \mathrm{yr}^{-1}$ in core Amvr13 (Fig. 2). Regarding core Amvr15, the estimated rate was in agreement with the one calculated by Tsabaris et al. (2011) from the same area. From the vertical profiles of ${ }^{210} \mathrm{~Pb}$, no significant bioturbation was observed. Based on the age models (Fig. 2), the cores comprised sediments deposited since 1940 (Amvr15) and 1975 (Amvr13).

\subsection{Benthic foraminifera}

Benthic foraminifera were present throughout both cores. A total of 127 foraminiferal species were recognized in samples from core Amvr15. The number of benthic foraminifera specimen per $\mathrm{g}$ of sediment was high, except in the inter-
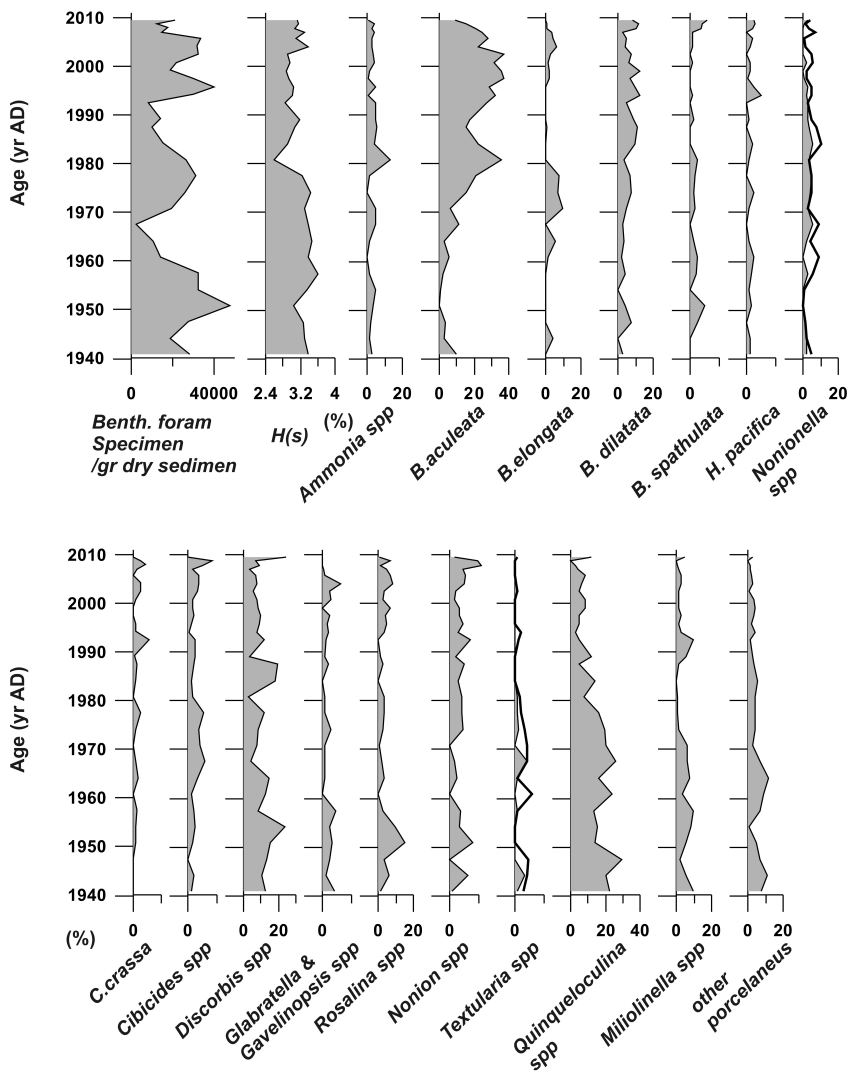

Fig. 3. Downcore changes of benthic foraminifera in per cent (\%) of the total benthic foraminifera assemblages in core Amvr15 versus sediment depth together with the indices of benthic productivity (benthic foraminifera specimen/g of dry sediment) and diversity $(H(s))$. Grey bands in the diagrams of Textularia spp. and Nonionella spp. indicate the relative amounts of T. agglutinans and $N$. turgida, respectively.

vals $25-30 \mathrm{~cm}$ (1960-1968), 10-15 cm (1985-1993), 6-7 cm (1998-2000) and 1-2 cm (2007-2008) (Fig. 3). The $H(s)$ diversity index ranged between 2.6 and 3.6 and exhibited lower values from around $18 \mathrm{~cm}$ (since ca. 1980) to the top of the core. Within the upper $3 \mathrm{~cm}$ of the core (since ca. 2005), the $H(s)$ index represented small-scale oscillation with low values in the dark colour laminae. Furthermore, at around $1 \mathrm{~cm}$ (ca. 2009) the reduction of the $H(s)$ index was accompanied by a reduction of the benthic foraminifera population. A shift of both indices to higher values occurred in the light-coloured muddy sediments at the core top. The downcore variation of the abundances of selected taxa is shown in Fig. 3.

Benthic foraminifera assemblages consisted of miliolids (Quinqueloculina seminulum, Quinqueloculina $o b$ longa, Quinqueloculina laevigata, Quinqueloculina stelligera, Quinqueloculina lata, Quinqueloculina subpoeyana, Miliolinella subrotunda, Triloculina spp.), epifaunal (Rosalina globularis, Discorbis spp., Planorbulina mediterranensis, Cibicides spp.) and infaunal taxa (Bulimina aculeata, Bolivina dilatata, Bolivina spathulata, Ammonia beccarii, 


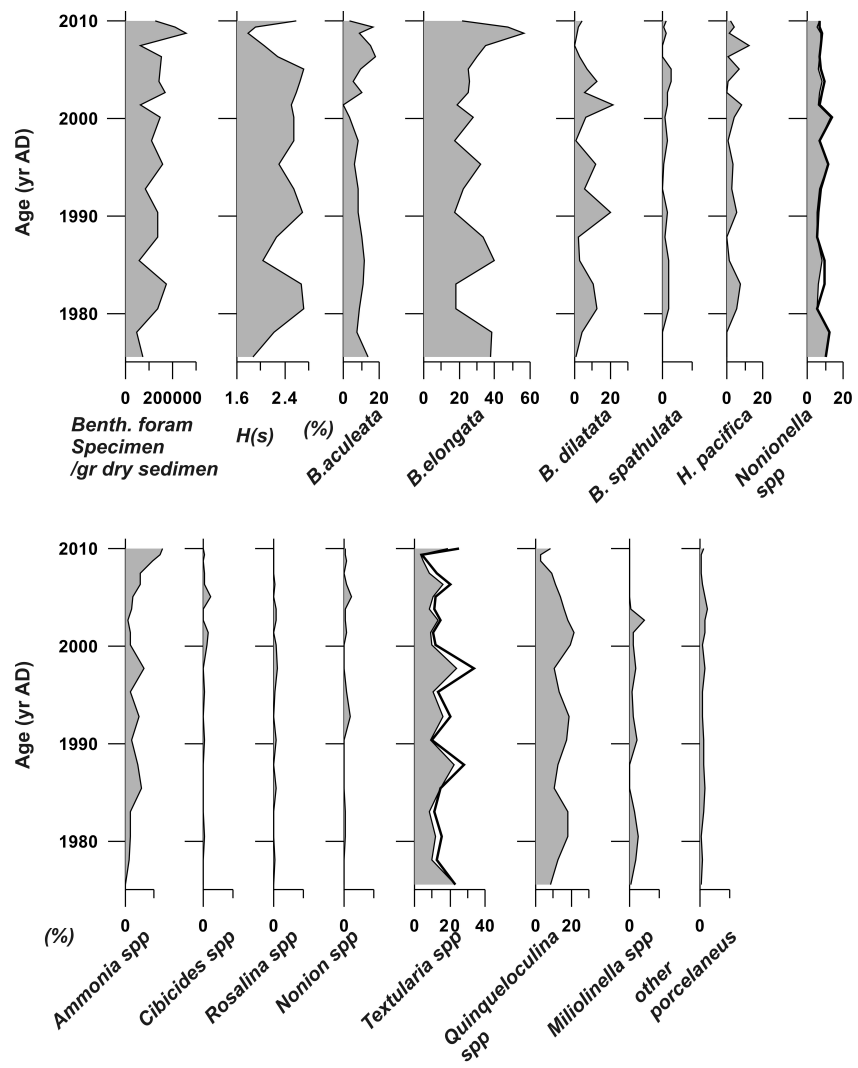

Fig. 4. Downcore changes of benthic foraminifera in per cent $(\%)$ of the total benthic foraminifera assemblages in core Amvr13 versus sediment depth, together with the indices of benthic productivity (benthic foraminifera specimen/g of dry sediment) and diversity $(H(s))$. Grey bands in the diagrams of Textularia spp. and Nonionellaspp. indicate the relative amounts of T. agglutinans and $N$. turgida, respectively.

Ammonia tepida, Nonion depressum, Nonionella turgida and Nonionella bradii).

A total of 77 foraminiferal species were recognized in samples from core Amvr13 (Fig. 4). The $H(s)$ diversity index ranged between 1.8 and 2.7 and exhibited lower values at around $20 \mathrm{~cm}$ (ca. 1985) and $1 \mathrm{~cm}$ depth (ca. 2009). Shallow and deep infaunal species dominated the benthic assemblages almost throughout the core, including high abundances of Bulimina elongata, Bulimina aculeata, Bolivina dilatata, Bolivina spathulata, Hopkinsina pacifica, Ammonia tepida, Nonionella turgida and Nonionella bradii. The agglutinated species included mostly Textularia conica and Textularia agglutinans and the porcelaneous species included Miliolids. Quinqueloculina spp. and Miliolinella spp. showed similar fluctuations and higher abundances at around $25 \mathrm{~cm}$ (ca. 1978), $15 \mathrm{~cm}$ (ca. 1992) and $8 \mathrm{~cm}$ (ca. 2000; Fig. 4).

\subsection{Bulk parameters and biomarkers}

The TOC profile of core Amvr13 increased slightly from 1.3 to $2.7 \mathrm{wt} \%$ towards the top of the core (Fig. 5). TN and $\delta^{15} \mathrm{~N}$ values and chlorin concentrations also increased (Fig. 5). The $\mathrm{CI}$ decreased towards the top of the core (Fig. 5). The C/N ratio was $\leq 9$ (Fig. 5). Total nitrogen contents were below the detection limit in 18-20 cm (1985-1988) and 2-3 cm (20062008 ), which hindered the calculation of the $\mathrm{C} / \mathrm{N}$ ratios. $\delta^{13} \mathrm{C}_{\mathrm{TOC}}$ values ranged between -23 to $-22 \%$ o throughout the core.

The concentrations of branched alkanes, isoprenoids and hopanoids (Fig. 6) were highest in 28-29 cm (1974-1975) and in the upper $10 \mathrm{~cm}$ (since about 1998). In contrast, they were lowest in 12-14 cm (1993-1995) (Fig. 6). Short chain $n$-alcohols, phytol, dinosterol (4,23,24-trimethylcholest$22 \mathrm{E}$-en-3 $\beta$-ol, 4-Me30 $\Delta 22$ ), $\beta$-sitosterol (24-ethylcholest7-en-3 $\beta$-ol, $\mathrm{C}_{29: 1} \Delta 7$ ) and tetrahymanol increased towards the surface sediment (Fig. 6). The $P_{\text {aq }}$ proxy is an indicator of macrophytes (Ficken et al., 2000) and ranged between 0.2 and 0.6 in both cores (Fig. 6). After hydrogenation, traces of isorenieratane and chlorobactane were found. Only in the lowermost sample of this core chlorobactane could not be detected. Lycopane concentrations and the (lycopane $+\mathrm{C}_{35} n$-alkane) $/ \mathrm{C}_{31} n$-alkane ratio increased with depth (Fig. 7). The alkenone-based $\mathrm{UK}_{37}$ index $\left(\mathrm{Me} \mathrm{C}_{37: 2} /\left[\mathrm{Me} \mathrm{C}_{37: 2}+\mathrm{MeC}_{37: 3}\right]\right.$; by Prahl and Wakeham, 1987) increased from 0.63 to 0.78 at the sediment surface (Fig. 8).

In core Amvr15, the TOC increased from 1.4 in the lowermost part to $6.1 \mathrm{wt} \%$ in the surface sediment (Fig. 5). TN and $\delta^{15} \mathrm{~N}$ values also increased (Fig. 5). Chlorin concentrations remained constant throughout the core with about $0.5 \mathrm{mg} \mathrm{g}^{-1}$ TOC (Fig. 5). The CI decreased towards the top of the core (Fig. 5). The $\mathrm{C} / \mathrm{N}$ ratio was $\geq 10$, but below $20 \mathrm{~cm}$ (before 1977) $\mathrm{C} / \mathrm{N}$ values ranged between 6 and 23 (Fig. 5). $\delta^{13} \mathrm{C}_{\mathrm{TOC}}$ values ranged between -19 to $-18 \%$ o throughout the core.

The concentrations of branched alkanes, isoprenoids and hopanoids were relatively constant throughout core Amvr15 (Fig. 6). Short chain $n$-alcohols, phytol, dinosterol and $\beta$ sitosterol increased quite continuously towards the surface sediment (Fig. 6). The $P_{\text {aq }}$ proxy is an indicator of macrophytes (Ficken et al., 2000) and ranged between 0.2 and 0.6 in both cores (Fig. 6). After hydrogenation, traces of isorenieratane and chlorobactane were found throughout the core. Tetrahymanol and lycopane concentrations and the (lycopane $+\mathrm{C}_{35} n$-alkane) $/ \mathrm{C}_{31} n$-alkane ratio remained constant in core Amvr15 (Figs. 6, 7). The alkenone-based UK' 37 index (Me $\mathrm{C}_{37: 2} /\left[\mathrm{Me} \mathrm{C}_{37: 2}+\mathrm{Me} \mathrm{C}_{37: 3}\right.$ ]; by Prahl and Wakeham, 1987) increased towards the surface sediment from 0.61 to 0.84 (Fig. 8). 


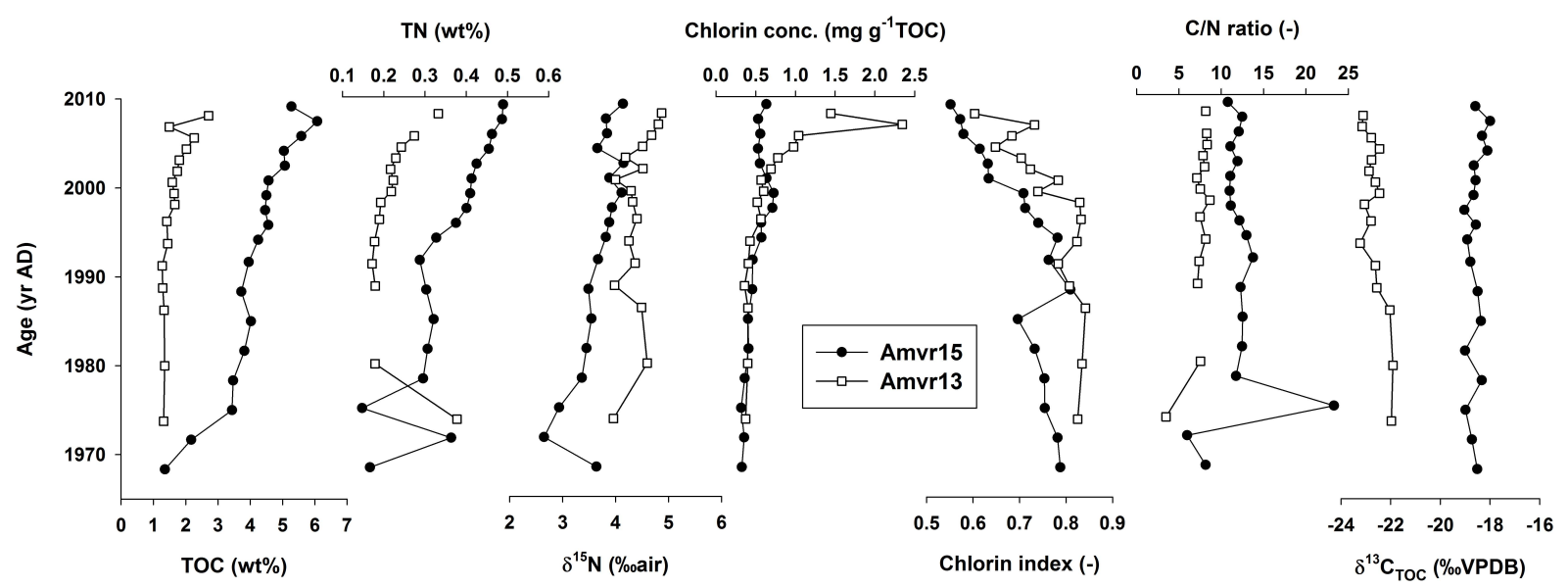

Fig. 5. Bulk parameters of cores Amvr13 and Amvr15 plotted vs. age (yr AD), including the concentrations of total organic carbon (TOC), total nitrogen $(\mathrm{TN})$, nitrogen isotopic composition $\left(\delta^{15} \mathrm{~N}, \%\right.$ air), chlorin concentrations $\left(\mathrm{mg} \mathrm{g}^{-1} \mathrm{TOC}\right)$, chlorin index $(\mathrm{CI})$, the $\mathrm{C} / \mathrm{N}$ ratio and the TOC isotopic composition $\left(\delta^{13} \mathrm{C}_{\mathrm{TOC}}, \%\right.$ VPDB).

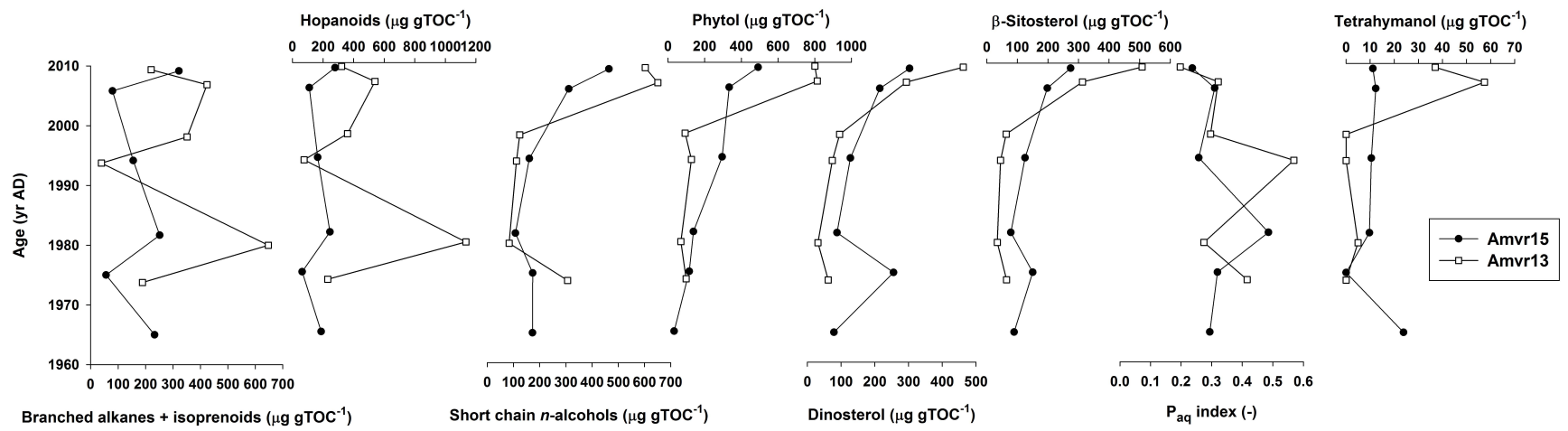

Fig. 6. Concentrations ( $\left.\mu \mathrm{g} \mathrm{g}^{-1} \mathrm{TOC}\right)$ of the sums of branched alkanes and isoprenoids, hopanoids, short chain $n$-alcohols $\left(\mathrm{C}_{11}-\mathrm{C}_{20}\right)$, phytol, dinosterol, $\beta$-sitosterol, $P_{\text {aq }}$ index (by Ficken et al., 2000) and tetrahymanol plotted vs. age (yr AD).

\section{Discussion}

\subsection{Benthic foraminifera abundance}

In core Amvr15, epifauna species dominated the benthic assemblages between 20 and $42 \mathrm{~cm}$ (1940-1977; Fig. 3) suggesting adequate oxygen levels of the bottom water (Murray, 2006). The increased participation of diverse Quinqueloculina spp., Rosalina spp., Cibicides spp. together with Planorbulina mediterranensis and other epifauna species may also be attributed to the presence of seagrass meadows colonized locally on the coring site (Murray, 2001; MateuVicens et al., 2010). Furthermore, the presence of Cibicides spp. could also be related to the hydrodynamic regime at the coring site since high abundances of these taxa are related to high current velocities (Szarek et al., 2006). Infaunal species showed increased abundances in the upper $20 \mathrm{~cm}$ (since ca. 1977) indicating reduced oxygen levels in the bottom water (Murray, 2006). In this interval Bulimina aculeata dominated the benthic assemblages with up to $40 \%$ of the total associ- ation (Fig. 3). This taxon occurs predominantly surficial and reacts quickly to labile OM supply (Mojtahid et al., 2010).

In core Amvr13 the higher abundance of shallow and deep infaunal species indicated less favourable oxygenated conditions in relation to those of core Amvr15. All the dominant species in the benthic foraminiferal assemblages of this core (Bulimina elongata, Bulimina aculeata, Bolivina dilatata, Bolivina spathulata, Hopkinsina pacifica, Ammonia tepida, Nonionella turgida and $N$. bradii) have been reported as common in shelf environments, associated with high contents of OM, and being stress-tolerant taxa (Jorissen, 1987; Barmawidjaja et al., 1995; van der Zwaan, 2000; Mendes et al., 2004; Murray, 2006).

\subsection{Benthic foraminifera clusters}

Cluster analysis (R-mode) revealed four clusters (Fig. 9). Cluster I was composed of Bulimina elongata, Nonionella turgida, Textularia agglutinans and Ammonia tepida (Fig. 9). In many studies Nonionella turgida appears as the most 


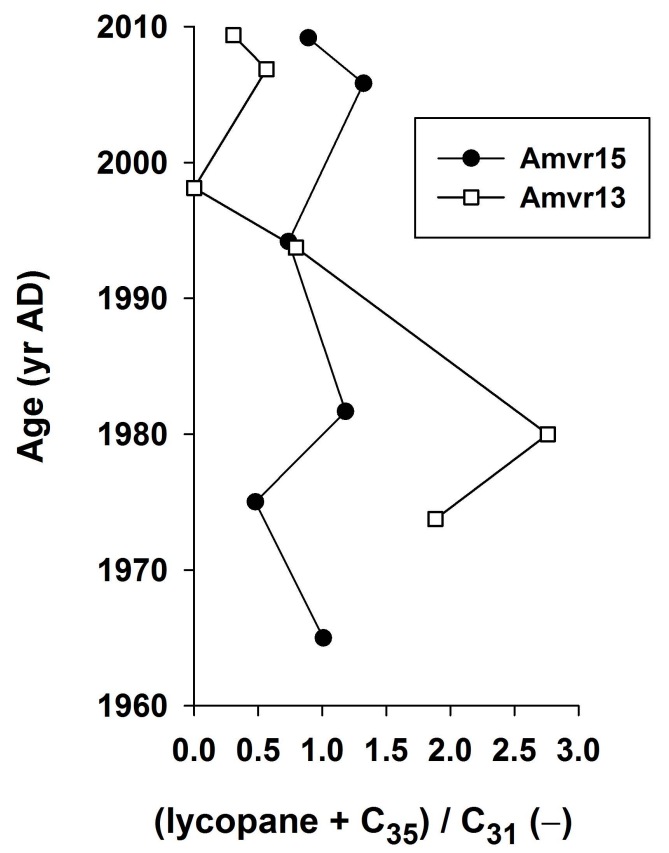

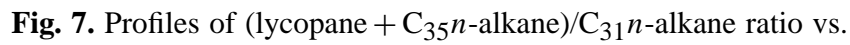
age (yr AD).
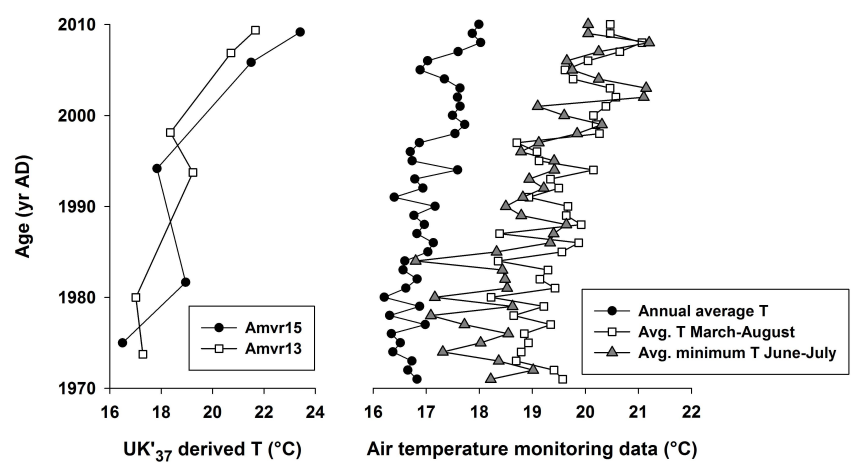

Fig. 8. UK' 37 index-derived surface water temperatures (left) according to the correlation of Müller et al. (1998), $\mathrm{UK}^{\prime}{ }_{37}=0.033 T+0.069\left(R^{2}=0.981\right)$ with $T=$ mean annual sea surface temperature, plotted vs. age (yr AD). For comparison, air temperature data $\left({ }^{\circ} \mathrm{C}\right)$ between 1970 and 2010 from the meteorological station Preveza (Aktio) were added (data from the Hellenic National Meteorological Service and http://www.weatheronline.co.uk): annual average air temperatures, average air temperatures of March-August, average minimum air temperatures of June-July.

tolerant species to oxygen depletion and its increase in abundance is associated with enhanced OM supply (Sen Gupta and Machain-Castillo, 1993; Blackwelder et al., 1996), usually of terrestrial origin (Mojtahid et al., 2010; Goineau et al., 2011). Ammonia tepida is considered as a species that is tolerant to large environmental variations (Almogi-Labin et al., 1992; Debenay and Guillou, 2002), including hypoxia (Blackwelder et al., 1996) and anthropogenic pollu-

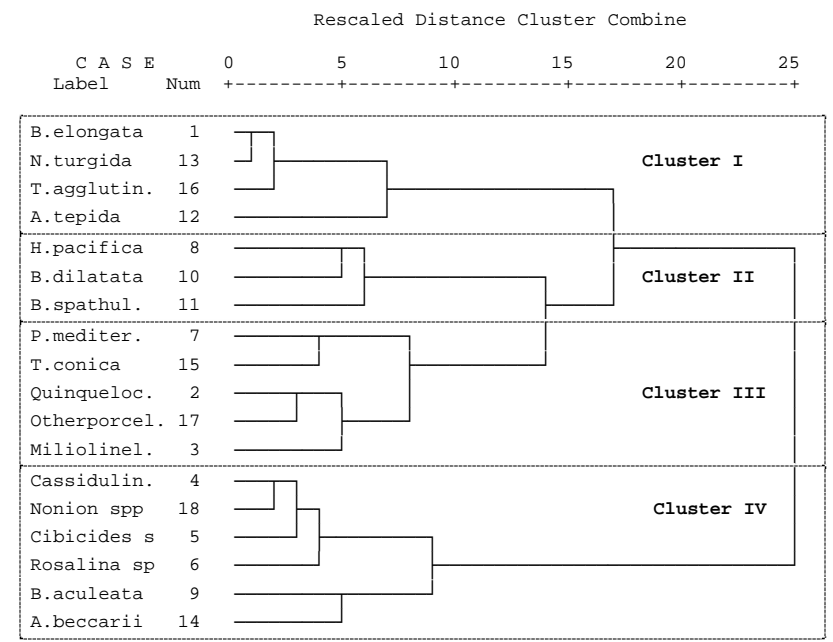

Fig. 9. R-mode cluster analysis for the entire dataset of the two cores.

tion (Debenay et al., 2005). Bulimina elongata is associated with food-enriched sediments related to river plumes (Guadiana River, Iberia; Mendes et al., 2004), closed embayment regimes (Yugoslavia; Murray, 2001) and fish farming products (Croatia; Vidović et al., 2009). Textularia agglutinans is an opportunistic species and exhibits a preference for food-enriched conditions and a tolerance to oxygen deficiency (Barmawidjaja et al., 1995). Furthermore, Nonionella turgida (as N. opima) and Textularia agglutinans are major species correlated with a high OM content in areas influenced by the Po River to the Adriatic Sea (Jorissen, 1987; Murray, 2001).

Cluster II was composed of Hopkinsina pacifica, Bolivina dilatata and Bolivina spathulata (Fig. 9). All these species are known to occur in benthic assemblages of oxygen-poor and organic-rich environments (Sen Gupta and MachainCastillo, 1993; Mendes et al., 2004; Murray, 2006). However, their low degree of opportunism (Barmawidjaja et al., 1995) in combination with their presence in areas of a river-influenced outer shelf (Bolivina spp.; Goineau et al., 2011) and of well-oxygenated substrates (Hyams-Kaphzan et al., 2009) suggests that Cluster II should represent benthic foraminiferal associations in lower stress environments than these of Cluster I.

Cluster III was composed of Quinqueloculina spp., Miliolinella spp., other porcelaneous species, Textularia conica and Planorbulina mediterranensis (Fig. 9). High abundances of Quinqueloculina spp. and in general Miliolids were found in oligotrophic environments and at sufficient bottom water oxygen concentrations (Blackwelder et al., 1996; Murray, 2006; Hyams-Kaphzan et al., 2009). Furthermore, the reduction in abundance of both porcelaneous and agglutinated groups of benthic foraminifera was used to trace palaeohypoxic evolution (Platon et al., 2005). 
Cluster IV was composed of Cassidulina spp., Nonion spp., Cibicides spp., Rosalina spp., Bulimina aculeata and Ammonia beccarii (Fig. 9). Species belonging to the genera of Cibicides, Rosalina, Nonion and Ammonia are known as epiphytic in the Mediterranean Sea (Murray, 2001; MateuVicens et al., 2010). However, Bulimina aculeata (Goineau et al., 2011) and Ammonia beccarii (Debenay et al., 2005) have been reported in high abundances on the seaward part of shelves with high OM supply. A similar trend exhibited species belonging to the genera of Cibicides and Rosalina, which have been reported in high abundances seaward on shelves under the influence of aquaculture products (Croatia; Vidović et al., 2009).

The downcore fluctuations in the abundance of the benthic species of Cluster I compared to the upper core could be used to trace high OM supply and oxygen depletion. Cluster II would represent similar environments, but under lower stress conditions. The abundances of the benthic foraminifera species of Cluster III could be used to trace environments of well-oxygenated conditions and those of Cluster IV of similar environments, but most likely influenced by higher marine OM input and/or seagrass development.

\subsection{Eutrophication, productivity and OM sources}

The TOC increased in both cores with time (Fig. 5), which explains the darker colour in the top part of the core. This can be explained by an increased productivity and a higher OM supply recently, which is also supported by the increase in TN values in both cores (Fig. 5). On the other hand the decrease of TOC and TN with depth could also be the result of progressive remineralisation within the sediment. However, the higher abundance of foraminiferal species belonging to Cluster I in core Amvr13 and Cluster IV species in core Amvr15 suggests a larger OM input (Fig. 10; Sen Gupta and Machain-Castillo, 1993; Blackwelder et al., 1996; Debenay et al., 2005; Goineau et al., 2011). Also other processes like oxygen availability or degree of opportunism can affect the abundance of these species (Sen Gupta and MachainCastillo, 1993; Barmawidjaja et al., 1995; Murray, 2006), which might explain that species belonging to Cluster II did not increase. Many biomarkers also traced an enhanced productivity with time, for instance by the increase in short chain $n$-alcohols, phytol and dinosterol towards the uppermost sediment in both cores (Fig. 6). These markers indicated an increased abundance of primary producers (Meyers and Ishiwatari, 1993; Rontani and Volkman, 2003; Volkman, 2003). Dinosterol is of diatom origin in Amvrakikos Gulf, because $\mathrm{C}_{22: 6} \mathrm{FA}$, which would hint to dinoflagellates as the source organisms (Withers, 1983; Volkman, 2003), is absent. The higher productivity is a direct result of progressive eutrophication in the gulf, as suggested by increasing $\delta^{15} \mathrm{~N}$ values, which have been used to reconstruct sewage supply and eutrophication in other settings (Cole et al., 2004; Wu et al., 2006). The higher chlorin concentrations in core Amvr13 within the most recent decade (Fig. 5) agree with this explanation. In contrast, the constant chlorin levels throughout core Amvr15 indicated that productivity hardly changed at this site.

The $\mathrm{C} / \mathrm{N}$ ratio below 10 (Fig. 5) indicated that the $\mathrm{OM}$ in core Amvr13 originated mainly from algal sources, in agreement with observations in other settings (Meyers and Ishiwatari, 1993). In contrast, the higher $\mathrm{C} / \mathrm{N}$ ratios in core Amvr15 suggested significant supply of terrestrial vascular plant-derived OM sources (Fig. 5). The constant $\delta^{13} \mathrm{C}_{\mathrm{TOC}}$ values throughout both cores indicated that the $\mathrm{OM}$ source remained constant during the last decades. The $\delta^{13} \mathrm{C}_{\mathrm{TOC}}$ values in Amvr15 (average: $-18.6 \%$; Fig. 5) are typical of marine $\mathrm{OM}$, whereas terrigenous $\mathrm{OM}$ sources average at $-26 \%$ (Sackett, 1964; Jasper and Gagosian, 1990). The lower $\delta^{13} \mathrm{C}_{\mathrm{TOC}}$ values in Amvr13 (average: -22.6\%; Fig. 5) might indicate mixed marine and terrigenous sources, but this explanation disagrees with the low $\mathrm{C} / \mathrm{N}$ values (Fig. 5), which are characteristic of a predominantly marine OM origin (Meyers and Ishiwatari, 1993). Therefore, the lower $\delta^{13} \mathrm{C}_{\mathrm{TOC}}$ values in Amvr13 were more likely the result of mixing and uptake of dissolved inorganic carbon derived from OM degradation, which can lead to isotopic shifts towards depleted values in eutrophic systems (van Breugel et al., 2006). This would mean that Amvrakikos Gulf is not in equilibrium with the atmosphere. Therefore, complicating factors that can affect the $\delta^{13} \mathrm{C}_{\mathrm{TOC}}$ like the Suess effect (McCarroll and Loader, 2004; Meyers, 2006) are expected to be of minor importance in Amvrakikos Gulf.

The relatively enriched $\delta^{13} \mathrm{C}_{\mathrm{TOC}}$ values in core Amvr15 most likely resulted from additional OM input by seagrass meadows, which were present at this sampling location. In the western Mediterranean Sea, it was shown that the presence of seagrass meadows led to an overprint of the OM in the sediment (Papadimitriou et al., 2005). $\delta^{13} \mathrm{C}_{\mathrm{TOC}}$ values were enriched at sites with seagrass meadows compared to sites with predominantly phytoplankton-derived OM sources by $4-6 \%$, which is well within the observed offset between cores Amvr15 and Amvr13. Furthermore, seagrass meadows can lead to $2-3 \%$ o depleted $\delta^{15} \mathrm{~N}$ values (Papadimitriou et al., 2005), which would also explain lower $\delta^{15} \mathrm{~N}$ values in Amvr15.

$\beta$-Sitosterol is the major sterol of emersed macrophytes (Volkman, 1986). Therefore, seagrass might be a main source of this marker at least in Amvr15 (Fig. 6). The high $P_{\text {aq }}$ index above 0.2 in both cores (Fig. 6) traced the predominance of mid-chain over long chain $n$-alkanes (Ficken et al., 2000), which indicated that macrophytes are predominant lipid sources compared to higher land plant sources.

The disagreement between constant chlorin concentrations and the increase of many lipid biomarkers in Amvr15 (for instance short chain $n$-alcohols, phytol, dinosterol, $\beta$-sitosterol; Figs. 5, 6) indicated that degradation also affected the biomarker profiles. The CI is an estimate of the OM freshness (Schubert et al., 2005). CI values obtained in 

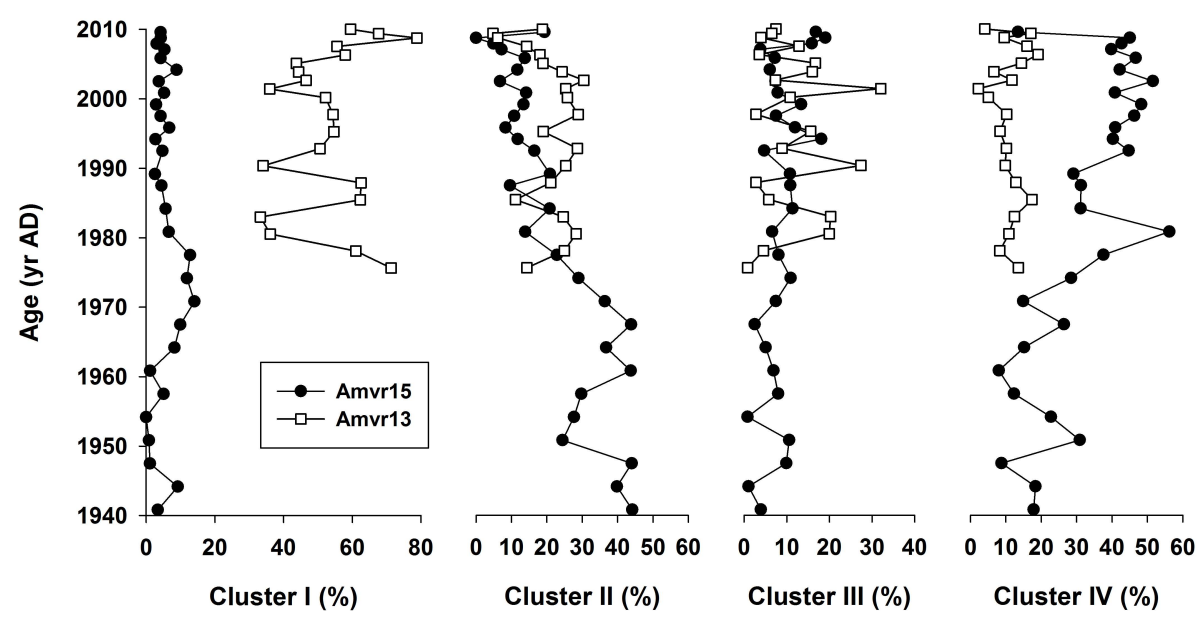

Fig. 10. Downcore variations of the sum abundances of the benthic foraminifera clusters (I-IV) in cores Amvr13 and Amvr15 vs. age (yr AD).

the gulf sediment indicated a lower degree of degradation in the uppermost part of both cores (Fig. 5). The CI values were higher in core Amvr13 (Fig. 5), indicating higher degradation rates at this location. These results suggest that the increase in concentration of many biomarkers (for instance short chain $n$-alcohols, phytol, dinosterol, $\beta$-sitosterol; Fig. 6) is also affected by degradation. In agreement with the constant chlorin concentrations in Amvr15 (Fig. 5), the slight biomarker concentration decrease in this core might be due to degradation. But the much higher increase in biomarker concentrations in Amvr13 (for instance short chain $n$-alcohols, phytol, dinosterol, $\beta$-sitosterol; Fig. 6) must be mainly due to a higher productivity, which is supported by the increase in chlorin concentrations in this core (Fig. 5).

\subsection{Impact of eutrophication on benthic foraminifera and bacteria - hypoxia reconstructions in the gulf}

The increase in population of benthic foraminiferal assemblages was associated with a decreasing diversity as depicted by the high negative correlation between the $H(s)$ and the benthic productivity indices (Pearson coefficient $r=-0.71$, $p<0.01)$ for the entire dataset of the cores. This is in contrast to the usual trend of microfauna, which appeared less diverse and less abundant in stressful, fluctuating environments (Blackwelder et al., 1996). However, the sediments of the gulf are under the influence of fish farming and urban waste. Eutrophication can lead to an increase in benthic foraminifera density (Angel et al., 2000) in conjunction with a decrease of diversity where the opportunistic species are dominant (Debenay et al., 2005). Therefore, the summed abundances of the benthic species of Clusters I and II showed high positive correlation with the benthic productivity index (Pearson coefficient $r=0.83, p<0.01$ ) and high negative correlation with the diversity index $(r=-0.87, p<$ $0.01)$ for the entire dataset. The opposite trend represents the summed abundances of the benthic species of Clusters III and IV, which showed high positive correlation with the diversity index (Pearson coefficient $r=0.72, p<0.01$ ) and negative correlation with the benthic productivity index $(r=-0.74$, $p<0.01$ ) for the entire dataset.

The benthic foraminifera in core Amvr13 represent low diversity, but high abundance assemblages (Fig. 10). The coring site of core Amvr13 is under the influence of large OM supply and stratified water masses promoting the development of low oxygen bottom water. This bottom-water environment is suggested by the dominance of species of Cluster I and II compared to those of Cluster III and IV. Furthermore, fluctuations in the abundances of the four clusters in conjunction with fluctuations in the benthic abundance and diversity index indicate fluctuating sea bottom environmental changes for the last $35 \mathrm{yr}$. The development of more unfavourable benthic environments occurred at around 19851988, 1994-1997 and after 2000, as shown by the decreasing abundances of species belonging to Cluster III, whereas the number of species of Cluster I increased (Fig. 10).

Branched alkanes, isoprenoids and hopanoids are bacterial biomarkers (Rohmer et al., 1984; Summons et al., 2007). These compounds indicated a higher bacterial biomass around 1980 and since the end of the 1990s in core Amvr13 (Fig. 6). The profiles of these markers were especially similar to Bulimina aculeata (Fig. 3), which is indicative of a higher supply of OM and severe oxygen depletion. These results suggest that the higher supply of OM has led to increased OM mineralisation and oxygen consumption rates. These developments might be related to aquacultures, which started around 1980 and excessively supplied nutrients and OM to the gulf (Ferentinos et al., 2010; Kountoura and Zacharias, 2011). Furthermore, mass mortality events of fish and reduction of fish populations in aquaculture rafts were observed between 1988 and 1997 (Ferentinos et al., 2010). 
The most stressful conditions started at around 2000, as recorded by a gradual increase in the abundance of species of Cluster I together with decreasing abundances of Cluster III species. These conditions peaked with the almost absence of species that belong to Cluster III in 2008 at the time of the recently recorded seasonal hypoxic event in the gulf. However, the rapid increase of Cluster III species and the $H(s)$ index shortly after the event suggests a fast recovery of the benthic environment (Fig. 10). These conditions starting at around 2000 and peaking in 2008 were already indicated by higher concentrations of bacterial biomarkers since the mid/late 1990s (Fig. 6). These increased concentrations were in good agreement with the intensified productivity (Sect. 5.3) and the resulting higher OM supply to the sediment, which had the same implications as during the 1980s.

In contrast, the constant abundance of chlorins and lower concentrations of bacterial markers throughout core Amvr15 indicated less severe conditions than at site Amvr13 without significant changes in productivity and OM supply (Figs. 5, 6). Benthic foraminifera assemblages at site Amvr15 appeared to be less productive and more diversified than those of core Amvr13. The dominance of species belonging to Cluster III and IV (Fig. 10) suggested lower OM supply, hence, higher sea floor oxygenation. This can be attributed to the location of site Amvr15 at the entrance of the gulf characterized by sufficient oxygen supply due to the water replenishment from the Ionian Sea (Ferentinos et al., 2010). Tziavos and Vouloumanos (1994) also reported a reduction of the benthic diversity eastwards in the surface sediments of the gulf. The observation of seagrass meadows at site Amvr15 and their absence at site Amvr13 further supports the lower impact of eutrophication (Green and Short, 2003).

More opportunistic species of Cluster IV replaced Cluster III species at site Amvr15 during times of nutrient enrichment and oxygen depletion (Fig. 10). This was especially the case between 1976 and 1980, the time interval when aquaculture development started. However, the reduction of species of both Clusters III and IV at 1985-1987 and 1995-1997 (Fig. 10) and a higher bacterial biomass around 1980 (Fig. 6) coincided with relative changes at site Amvr13, which suggested similar control mechanisms and time synchronicity in the bottom water oxygen regime between the two coring sites. Furthermore, similar to site Amvr13, the most severe sea floor conditions with respect to oxygen at site Amvr15 appeared in 2008 as suggested by the almost absence of species belonging to Cluster III and a higher bacterial biomass around that time (Figs. 6, 10). This indicates that the effects of that hypoxic event did not only influence the benthic fauna of the inner part of the gulf, but were also spread in areas that are considered as throughout the year being well oxygenated. However, the impact of hypoxia on the benthic microfauna at the bottom of the gulf entrance was less intense than that occurred in the inner part of the gulf, since species considered being sensitive to hypoxia (Clus- ter IV) were still highly abundant (Fig. 10) and seagrass meadows were also present at this site.

Furthermore, the more severe oxygen depletion at Amvr13 compared to Amvr15 was also indicated by the increase of the (lycopane $+\mathrm{C}_{35} n$-alkane) $/ \mathrm{C}_{31} n$-alkane ratio with depth (Fig. 7). Although the source of lycopane is unknown, it has been used to reconstruct palaeo-redox conditions in the bottom water in marine settings (Wakeham et al., 1993; Sinninghe Damsté et al., 2003). In contrast, the quite constant ratio in core Amvr15 (Fig. 7) suggested enhanced oxygen concentrations.

Isorenieratane and chlorobactane are tracers for phototrophic sulfur bacteria (Chlorobiaceae) and hence phototrophic zone euxinia and anoxia (Brocks and Summons, 2003). The observation of these carotenoids throughout both cores indicated regularly occurring developments of anoxic and euxinic conditions reaching into the photic zone at both sites. The monitoring data showed that oxygen depletion has occurred seasonally during summer and fall in the western part of the gulf (Ferentinos et al., 2010; Kountoura and Zacharias, 2011). Due to the low concentrations of these pigments in the sediment of both cores, only the existence of photic zone anoxia but no temporal changes could be reconstructed.

\subsection{Impact of climate on stratification and oxygen replenishment}

Stratification is another key factor in the oxygen budget of the gulf water column, because oxygen is resupplied by mixing. A repeatedly used indicator for stratification, stagnation and/or salinity is tetrahymanol, which is found in bacteriovoric ciliates (Sinninghe Damsté et al., 1995; Thiel et al., 1997; Bechtel and Schubert, 2009). The relatively constant tetrahymanol concentrations in core Amvr15 (Fig. 6) suggested that stratification did not change since the 1970s. In contrast, the increase of tetrahymanol in the uppermost part of core Amvr13 (Fig. 6) clearly showed a higher stratification and stagnation, probably due to higher water temperatures and/or salinities in the gulf. To prove these relationships, sedimentary proxies were compared with monitoring data.

The $\mathrm{UK}_{37}$ index $\left(\mathrm{Me} \mathrm{C}_{37: 2} /\left[\mathrm{Me} \mathrm{C}_{37: 2}+\mathrm{MeC}_{37: 3}\right]\right.$; by Prahl and Wakeham, 1987) is an alkenone-based proxy, which is highly correlated with mean annual sea surface temperatures (Prahl et al., 1988; Müller et al., 1998). Alkenones are specific for haptophyte algae (Herbert, 2003). The temperature calibration of Prahl et al. (1988) yielded values between 16.9 and $23.6^{\circ} \mathrm{C}$ and between 17.4 and $21.9^{\circ} \mathrm{C}$ in cores Amvr15 and Amvr13, respectively. For comparison, the temperature calibration by Müller et al. (1998), which is based on sediment core top samples worldwide, yielded very similar results $\left(16.5-23.4^{\circ} \mathrm{C}\right.$ in core Amvr15 and 17.0-21.7 ${ }^{\circ} \mathrm{C}$ in Amvr13; Fig. 8). The difference between 
estimated surface water temperatures using both calibrations was only up to $0.4^{\circ} \mathrm{C}$.

The temperature estimates from both cores indicated a trend with increased surface water temperatures, which matched well with increasing air temperatures observed at the Preveza (Aktio) weather station during the last decades (Fig. 8). The UK' ${ }_{37}$-derived surface water temperatures in both cores $\left(16.5-23.4^{\circ} \mathrm{C}, 1974-2010\right.$; Fig. 8) were within the range of monitored average annual minimum and maximum air temperatures with values between about 12 and $22^{\circ} \mathrm{C}$ (1970-2010), except the uppermost part of core Amvr15 with larger UK' 37 temperature estimates. The annual average air temperatures ranged between 16.2 and $18.0^{\circ} \mathrm{C}(1970$ 2010), and were lower than estimated UK' 37 temperatures (Fig. 8). Although the timing of blooms of the source organisms is unknown for Amvrakikos Gulf, the best agreement between UK' ${ }_{37}$-derived and monitored temperatures was obtained by using the average temperature of March until August. The air temperatures ranged from 18.2 to $21.1^{\circ} \mathrm{C}$ (1970-2010; Fig. 8; data from the Hellenic National Meteorological Service and http://www.weatheronline.co.uk). The monitoring data showed that especially the annual minimum temperatures increased during the last decades, whereas the annual maximum temperatures hardly increased. By using only monthly average minimum temperature data, the best fit was obtained with the average minimum temperature data of June and July with a range of $16.8-21.2{ }^{\circ} \mathrm{C}$ (Fig. 8). These results indicated that alkenones might have captured the lowermost surface water temperatures during June and July. In contrast, this and other calibrations showed strong correlations either with annual average temperatures or seasonal average temperatures at times of blooms (Prahl et al., 1988; Müller et al., 1998; Herbert, 2003). Therefore, a shift of the time of blooms from spring towards summer is more likely, which would also explain the large increase in estimated temperatures during the last decades.

Nonetheless, the warming trend of UK' 37 -derived temperatures together with the monitoring data indicated that the surface water temperatures in Amvrakikos Gulf increased during the last decades. Previous studies showed that steep temperature gradients separate surface and bottom waters (Ferentinos et al., 2010). Higher temperatures in the surface water may further increase these differences, which can explain the observation of a higher stratification during the last years.

Furthermore, also salinity controls stratification by steep salinity gradients in the water column due to the inflow of high salinity water masses through the Preveza Strait from the Ionian Sea and brackish water outflow (Ferentinos et al., 2010). This circulation pattern is similar to the Black Sea; however, the reduced outflow of the Black Sea prevents the reduction of its permanent stratification (Ozsoy and Unluata, 1997; Murray et al., 2007), which is not the case for Amvrakikos Gulf (Ferentinos et al., 2010). However, the similar developments regarding circulation patterns, eutrophica- tion and temperature have led to a strong decrease in oxygen concentrations, which resulted in mass mortality events and ecosystem collapse in both settings (Lancelot et al., 2002; Mee et al., 2005; Ferentinos et al., 2010; Kountoura and Zacharias, 2011).

\section{Conclusions}

The analysis of benthic foraminifera and lipid biomarkers revealed that Amvrakikos Gulf exhibited dramatic environmental changes due to eutrophication during the last decades. The higher productivity and OM supply to the sediment (higher concentrations of chlorins, TOC, TN and $\delta^{15} \mathrm{~N}$ values) led to a higher abundance of tolerant and opportunistic benthic species and bacteria, whereas the benthic species density decreased. Especially the increased abundance of species from Cluster I (Bulimina elongata, Nonionella turgida, Textularia agglutinans, Ammonia tepida) together with a decreasing abundance of Cluster III species (Quinqueloculina spp., Miliolinella spp., other porcelaneous, Textularia conica, Planorbulina mediterranensis) indicated more severe OM supply and oxygen depletion in 1976, 1980, 1985-1987, 1995-1997, 2000 and 2008. Cluster III and IV species (Cluster IV: Cassidulina spp., Nonion spp., Cibicides spp., Rosalina spp., Bulimina aculeata, Ammonia beccarii) rapidly recovered after environmental disturbances. In core Amvr15 the benthic assemblages appeared to be less productive and more diversified with a dominance of species of Clusters III and IV under conditions of lower OM supply and higher bottom water oxygen concentrations than in core Amvr13. The presence of seagrass at site Amvr15 largely influenced the values of $\delta^{13} \mathrm{C}_{\mathrm{TOC}}, \mathrm{C} / \mathrm{N}$ ratio and mid-chain $n$-alkanes. Nonetheless, the presence of isorenieratane and chlorobactane in both cores traced temporarily euxinic conditions in the photic zone throughout the gulf. The increasing air temperatures have led to stronger stratification and hence oxygen depletion during the last decade.

Acknowledgements. This study was funded by the European Union project "Hypox - In situ monitoring of oxygen depletion in hypoxic ecosystems of coastal and open seas and land-locked water bodies" (EC grant 226213). Karl Schubert is thanked for support during sampling. Marie-Eve Randlett (Eawag) is thanked for help with the analysis and data interpretation of alkenones. The article benefitted substantially from the critical review of H. Filipsson and an anonymous reviewer.

Edited by: C. P. Slomp 


\section{References}

Airoldi, L. and Beck, M. W.: Loss, status and trends for coastal marine habitats of Europe, Oceanogr. Mar. Biol., 45, 345-405, 2007.

Almogi-Labin, A., Perelis-Grossovicz, L., and Raab, M.: Living ammonia from a hypersaline inland pool, Dead Sea area, Israel, J. Foramin. Res., 22, 257-266, 1992.

Anastasakis, G., Piper, D. J. W., and Tziavos, C.: Sedimentological response to neotectonics and sea-level change in a deltafed, complex graben: Gulf of Amvrakikos, western Greece, Mar. Geol., 236, 27-44, 2007.

Angel, D. L., Verghese, S., Lee, J. J., Saleh, A. M., Zuber, D., Lindell, D., and Symons, A.: Impact of a net cage fish farm on the distribution of benthic foraminifera in the Northern Gulf of Eilat (Aqaba, Red Sea), J. Foramin. Res., 30, 54-65, 2000.

Appleby, P. G. and Oldfield, F.: The calculation of lead-210 dates assuming a constant rate of supply of unsupported ${ }^{210} \mathrm{~Pb}$ to the sediment, Catena, 5, 1-8, 1978.

Barmawidjaja, D. M., van der Zwaan, G. J., Jorissen, F. J., and Puskaric, S.: 150 years of eutrophication in the northern Adriatic Sea - Evidence from a benthic foraminiferal record, Mar. Geol., 122, 367-384, 1995.

Bechtel, A. and Schubert, C. J.: A biogeochemical study of sediments from the eutrophic Lake Lugano and the oligotrophic Lake Brienz, Switzerland, Org. Geochem., 40, 1100-1114, 2009.

Blackwelder, P., Hood, T., Alvarez-Zarikian, C., Nelsen, T. A., and McKee, B.: Benthic foraminifera from the NECOP study area impacted by the Mississippi River plume and seasonal hypoxia, Quatern. Int., 31, 19-36, 1996.

Brocks, J. J. and Summons, R. E.: Sedimentary hydrocarbons, biomarkers for early life, in: Treatise in Geochemistry, edited by: Holland, H. D. and Turekian, K., Biogeochemistry, 8, 65-115, Elsevier, Oxford, 2003.

Buzas, M. A. and Gibson, T. G.: Species diversity: Benthonic foraminifera in western North Atlantic, Science, 163, 72-75, 1969.

Cole, M. L., Valiela, I., Kroeger, K. D., Tomasky, G. L., Cebrian, J., Wigand, C., McKinney, R. A., Grady, S. P., and Carvalho da Silva, M. H.: Assessment of a $\delta^{15} \mathrm{~N}$ isotopic method to indicate anthropogenic eutrophication in aquatic ecosystems, J. Environ. Qual., 33, 124-132, 2004.

Debenay, J. P. and Guillou, J. J.: Ecological transitions indicated by foraminiferal assemblages in paralic environments, Estuaries, 25, 1107-1120, 2002.

Debenay, J. P., Millet, B., and Angelidis, M. O.: Relationships between foraminiferal assemblages and hydrodynamics in the Gulf of Kalloni, Greece, J. Foramin. Res., 35, 327-343, 2005.

Diaz, R. J. and Rosenberg, R.: Spreading dead zones and consequences for marine ecosystems, Science, 321, 926-929, 2008.

Ferentinos, G., Papatheodorou, G., Geraga, M., Iatrou, M., Fakiris, E., Christodoulou, D., Dimitriou, E., and Koutsikopoulos, C.: Fjord water circulation patterns and dysoxic/anoxic conditions in a Mediterranean semi-enclosed embayment in the Amvrakikos Gulf, Greece, Estuar. Coast. Shelf S., 88, 473-481, 2010.

Ficken, K. J., Li, B., Swain, D. L., and Eglinton, G.: An $n$-alkane proxy for the sedimentary input of submerged/floating freshwater aquatic macrophytes, Org. Geochem., 31, 745-749, 2000.

Filipsson, H. L. and Nordberg, K.: A 200-year environmental record of a low-oxygen fjord, Sweden, elucidated by benthic foraminifera, sediment characteristics and hydrographic data, J. Foramin. Res., 34, 277-293, 2004.

Goineau, A., Fontanier, C., Jorissen, F. J., Lansard, B., Buscail, R., Mouret, A., Kerhervé, P., Zaragosi, S., Ernoult, E., Artéro, C., Anschutz, P., Metzger, E., and Rabouille, C.: Live (stained) benthic foraminifera from the Rhone prodelta (Gulf of Lion, NW Mediterranean): Environmental controls on a river-dominated shelf, J. Sea Res., 65, 58-75, 2011.

Green, E. P. and Short, F. T.: World Atlas of Seagrasses, University of California Press, Berkeley, 2003.

Herbert, T. D.: Alkenone Paleotemperature Determinations, in: Treatise on Geochemistry, edited by: Heinrich, D. H. and Karl, K. T., Pergamon, Oxford, 391-432, 2003.

Hinrichs, K. U., Hmelo, L. R., and Sylva, S. P.: Molecular fossil record of elevated methane levels in late pleistocene coastal waters, Science, 299, 1214-1217, 2003.

Hyams-Kaphzan, O., Almogi-Labin, A., Benjamini, C., and Herut, B.: Natural oligotrophy vs. pollution-induced eutrophy on the SE Mediterranean shallow shelf (Israel): Environmental parameters and benthic foraminifera, Mar. Pollut. Bull., 58, 1888-1902, 2009.

Jasper, J. P. and Gagosian, R. B.: The sources and deposition of organic matter in the Late Quaternary Pigmy Basin, Gulf of Mexico, Geochim. Cosmochim. Ac., 54, 1117-1132, 1990.

Jorissen, F. J.: The distribution of benthic foraminifera in the Adriatic Sea, Mar. Micropaleontol., 12, 21-48, 1987.

Kapsimalis, V., Pavlakis, P., Poulos, S. E., Alexandri, S., Tziavos, C., Sioulas, A., Filippas, D., and Lykousis, V.: Internal structure and evolution of the Late Quaternary sequence in a shallow embayment: The Amvrakikos Gulf, NW Greece, Mar. Geol., 222, 399-418, 2005.

Kountoura, K. and Zacharias, I.: Temporal and spatial distribution of hypoxic/seasonal anoxic zone in Amvrakikos Gulf, Western Greece, Estuar. Coast. Shelf S., 94, 123-128, 2011.

Lancelot, C., Martin, J. M., Panin, N., and Zaitsev, Y.: The northwestern Black Sea: A pilot site to understand the complex interaction between human activities and the coastal environment, Estuar. Coast. Shelf S., 54, 279-283, 2002.

Mateu-Vicens, G., Box, A., Deudero, S., and Rodriguez, B.: Comparative analysis of epiphytic foraminifera in sediments colonized by seagrass Posidonia oceanica and invasive macroalgae Caulerpa spp., J. Foramin. Res., 40, 134-147, 2010.

McCarroll, D. and Loader, N. J.: Stable isotopes in tree rings, Quaternary Sci. Rev., 23, 771-801, 2004.

Mee, L. D., Friedrich, J., and Gomoiu, M. T.: Restoring the Black Sea in times of uncertainty, Oceanography, 18, 32-43, 2005.

Mendes, I., Gonzalez, R., Dias, J. M. A., Lobo, F., and Martins, V.: Factors influencing recent benthic foraminifera distribution on the Guadiana shelf (Southwestern Iberia), Mar. Micropaleontol., 51, 171-192, 2004.

Meyers, P.: An Overview of Sediment Organic Matter Records of Human Eutrophication in the Laurentian Great Lakes Region, Water, Air \& Soil Pollut. Focus, 6, 453-463, 2006.

Meyers, P. A. and Ishiwatari, R.: Lacustrine organic geochemistry an overview of indicators of organic matter sources and diagenesis in lake sediments, Org. Geochem., 20, 867-900, 1993.

Mojtahid, M., Jorissen, F., Lansard, B., and Fontanier, C.: Microhabitat selection of benthic foraminifera in sediments off the Rhone River mouth (NW Mediterranean), J. Foramin. Res., 40, 
231-246, 2010.

Müller, P. J., Kirst, G., Ruhland, G., von Storch, I., and RosellMelé, A.: Calibration of the alkenone paleotemperature index UK' 37 based on core-tops from the eastern South Atlantic and the global ocean $\left(60^{\circ} \mathrm{N}-60^{\circ} \mathrm{S}\right)$, Geochim. Cosmochim. Ac., 62 , 1757-1772, 1998.

Murray, J. W.: Ecology and Palaeoecology of Benthic Foraminifera, Longman Scientific and Technical, New York, 2001.

Murray, J. W.: Ecology And Applications of Benthic Foraminifera, Cambridge University Press, Cambridge, 2006.

Murray, J. W., Stewart, K., Kassakian, S., Krynytzky, M., and DiJulio, D.: Oxic, Suboxic and Anoxic Conditions in the Black Sea, in: The Black Sea Food Question: Changes in Coastline, Climate and Human Settlement, edited by: Yanko-Hombach, V., Gilbert, A. S., Panin, N., and Dolukhanov, P. M., Springer, 1-22, 2007.

Naeher, S., Smittenberg, R. H., Gilli, A., Kirilova, E. P., Lotter, A. F., and Schubert, C. J.: Impact of recent lake eutrophication on microbial community changes as revealed by high resolution lipid biomarkers in Rotsee (Switzerland), Org. Geochem., 49, 86-95, 2012.

Ozsoy, E. and Unluata, U.: Oceanography of the Black Sea: a review of some recent results, Earth-Sci. Rev., 42, 231-272, 1997.

Papadimitriou, S., Kennedy, H., Kennedy, D. P., Duarte, C. M., and Marba, N.: Sources of organic matter in seagrass-colonized sediments: A stable isotope study of the silt and clay fraction from Posidonia oceanica meadows in the western Mediterranean, Org. Geochem., 36, 949-961, 2005.

Platon, E., Sen Gupta, B. K., Rabalais, N. N., and Turner, R. E.: Effect of seasonal hypoxia on the benthic foraminiferal community of the Louisiana inner continental shelf. The 20th century record, Mar. Micropaleontol., 54, 263-283, 2005.

Prahl, F. G. and Wakeham, S. G.: Calibration of unsaturation patterns in long-chain ketone compositions for palaeotemperature assessment, Nature, 330, 367-369, 1987.

Prahl, F. G., Muehlhausen, L. A., and Zahnle, D. L.: Further evaluation of long-chain alkenones as indicators of paleoceanographic conditions, Geochim. Cosmochim. Ac., 52, 2303-2310, 1988.

Rohmer, M., Bouviernave, P., and Ourisson, G.: Distribution of hopanoid triterpenes in prokaryotes, J. Gen. Microbiol., 130, 1137-1150, 1984.

Rontani, J.-F. and Volkman, J. K.: Phytol degradation products as biogeochemical tracers in aquatic environments, Org. Geochem., 34, 1-35, 2003.

Sackett, W. M.: The depositional history and isotopic organic carbon composition of marine sediments, Mar. Geol., 2, 173-185, 1964.

Schubert, C. J., Niggemann, J., Klockgether, G., and Ferdelman, T. G.: Chlorin Index: A new parameter for organic matter freshness in sediments, Geochem. Geophy. Geosy., 6, Q03005, doi:10.1029/2004GC000837, 2005.

Scott, D. B., Piper, D. J. W., and Panagos, A. G.: Recent saltmarsh and intertidal mudflat foraminifera from the western coast of Greece, Rivista Italiana de Paleontologia e Stratigrafia, 85, 243 266, 1979.

Sen Gupta, B. K. and Machain-Castillo, M. L.: Benthic foraminifera in oxygen-poor habitats, Mar. Micropaleontol., 20, 183-201, 1993.

Shannon, C. E.: A mathematical theory of communication, Bell Syst. Tech. J., 27, 379-423, 1948.
Sinninghe Damsté, J. S., Irene, W., Rijpstra, C., de Leeuw, J. W., and Schenck, P. A.: Origin of organic sulphur compounds and sulphur-containing high molecular weight substances in sediments and immature crude oils, Org. Geochem., 13, 593-606, 1988

Sinninghe Damsté, J. S., Kenig, F., Koopmans, M. P., Koster, J., Schouten, S., Hayes, J. M., and De Leeuw, J. W.: Evidence for gammacerane as an indicator of water column stratification, Geochim. Cosmochim. Ac., 59, 1895-1900, 1995.

Sinninghe Damsté, J. S., Kuypers, M. M. M., Schouten, S., Schulte, S., and Rullkotter, R.: The lycopane/ $\mathrm{C}_{31}$-alkane ratio as a proxy to assess palaeoxicity during sediment deposition, Earth. Planet. Sc. Lett., 209, 215-226, 2003.

Smittenberg, R. H., Pancost, R. D., Hopmans, E. C., Paetzel, M., and Sinninghe Damsté, J. S.: A 400-year record of environmental change in an euxinic fjord as revealed by the sedimentary biomarker record, Palaeogeogr. Palaeocl., 202, 331-351, 2004.

Spitzer, V.: Structure analysis of fatty acids by gas chromatography low resolution electron impact mass spectrometry of their 4,4dimethyloxazoline derivatives - A review, Prog. Lipid Res., 35, 387-408, 1997.

Summons, R. E., Jahnke, L. L., and Simoneit, B. R. T.: Lipid Biomarkers for Bacterial Ecosystems: Studies of Cultured Organisms, Hydrothermal Environments and Ancient Sediments, in: Ciba Foundation Symposium 202 - Evolution of Hydrothermal Ecosystems on Earth and Mars, John Wiley and Sons, Chichester, 174-197, 2007.

Szarek, R., Kuhnt, W., Kawamura, H., and Kitazato, H.: Distribution of recent benthic foraminifera on the Sunda Shelf (South China Sea), Mar. Micropaleontol., 61, 171-195, 2006.

Thiel, V., Jenisch, A., Landmann, G., Reimer, A., and Michaelis, W.: Unusual distributions of long-chain alkenones and tetrahymanol from the highly alkaline Lake Van, Turkey, Geochim. Cosmochim. Ac., 61, 2053-2064, 1997.

Tsabaris, C., Evangeliou, N., Fillis-Tsirakis, E., Sotiropoulou, M., Patiris, D. L., and Florou, H.: Distribution of natural radioactivity in sediment cores from Amvrakikos gulf (Western Greece) as a part of IAEA's campaign in the Adriatic and Ionian Seas, Radiat. Prot. Dosimet., 1-14, 2011.

Tziavos, C. and Vouloumanos, N.: Microfaunal distribution in the surface sediments of Amvrakikos Gulf (Western Greece), Bulletin of the Geological Society of Greece, 30, 429-436, 1994.

van Breugel, Y., Schouten, S., Paetzel, M., and Sinninghe Damsté, J. S.: Seasonal variation in the stable carbon isotopic composition of algal lipids in a shallow anoxic fjord: Evaluation of the effect of recycling of respired $\mathrm{CO}_{2}$ on the $\delta^{13} \mathrm{C}$ of organic matter, $\mathrm{Am}$. J. Sci., 306, 367-387, 2006.

van der Zwaan, G. J.: Variation in Natural vs. Anthropogenic Eutrophication of Shelf Areas in Front of Major Rivers, in: Environmental Micropaleontology, edited by: Martin, R. E., Kluwer, New York, 385-404, 2000.

Vidović, J., Ćosović, V., Juračić, M., and Petricioli, D.: Impact of fish farming on foraminiferal community, Drvenik Veliki Island, Adriatic Sea, Croatia, Mar. Pollut. Bull., 58, 1297-1309, 2009.

Volkman, J. K.: A review of sterol markers for marine and terrigenous organic matter, Org. Geochem., 9, 83-99, 1986.

Volkman, J. K.: Sterols in microorganisms, Appl. Microbiol. Biot., 60, 495-506, 2003. 
Wakeham, S. G., Freeman, K. H., Pease, T. K., and Hayes, J. M.: A photoautotrophic source for lycopane in marine water columns, Geochim. Cosmochim. Ac., 57, 159-165, 1993.

Withers, N.: Dinoflagellate sterols, in: Marine Natural Products: Chemical and Biological Perspectives, edited by: Scheuer, P., Academic Press, New York, NY, 87-130, 1983.
Wu, J., Lin, L., Gagan, M., Schleser, G., and Wang, S.: Organic matter stable isotope $\left(\delta^{13} \mathrm{C}, \delta^{15} \mathrm{~N}\right)$ response to historical eutrophication of Lake Taihu, China, Hydrobiologia, 563, 19-29, 2006. 